ABSTRACT. . . . . . . . . . . . . . . . . . . . . 1

INTRODUCTION. . . . . . . . . . . . . . . . . . . . 1

ERDA/LLL Geothermal Project. ... . . . . . . . . . . . 1

Total Flow Concept . . . . . . . . . . . . . . . 5

LLL Site Requirements. . . . . . . . . . . . . . 7

PROJECT DESCRIPTION

Test objectives. . . . . . . . . . . . . . . . 7

Site Development ................... 8

Site operation ....................... 8

Project Administration .................. 11

ENVIRONMENTAL CONSIDERATIONS

Regulatory Agencies. . . . . . . . . . . . . . . 11

ERDA Environmental Program ................ 11

On-Site Environmental Program. . . . . . . . . . . 12

APPENDIX A. LLL Geotherma1 Development Program Overview. . . . . . . 14

APPENDIX B. Lease Conditions . . . . . . . . . . . . . 15

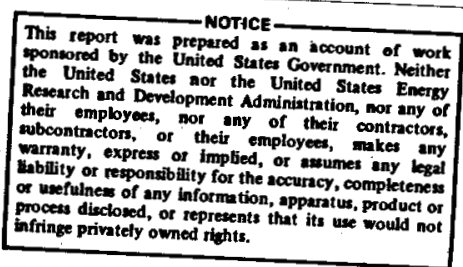




\section{GEOTHERMAL PROJECT DESCRIPTION \\ LLL EXPERIMENTAL SITE \\ SALTON SEA GEOTHERMAL FIELD}

\section{ABSTRACT}

The Lawrence Livermore Laboratory program for geothermal research requires the development of a field experimental facility in order to conduct a series of tests on turbine prototypes and to analyze the system requirements for power conversion. This report gives a description of the field portion of this experimental program including site development, test activities, and project administration. Additionally, it discusses plans for concurrent field environmental studies and surveillance programs. A series of maps are included to describe land ownership and lease status within the area of interest. Successful completion of the test program will prove the technology necessary for commercial development. An assessment of environmental factors indicates few temporary and no long term adverse environmental effects from this program.

\section{INTRODUCTION}

ERDA/LLL Geothermal Project

The Lawrence Livermore Laboratory (LLL) geothermal research program is being conducted under contract from the U. S. Energy Research and Development Administration (ERDA). This program aims to develop technology for producing useful forms of energy from high-temperature, high-salinity brines.

A large geothermal field of such brines has been identified by several agencies and is designated as the Salton Sea Known Geothermal Resource Area (KGRA), Fig. 1. Development of a number of geothermal wells within this area have served to define a producible field, designated by the state of California as the Salton Sea Geothermal Field (SSGF), Figs. 1 and 2.

Surface ownership within the SSGF is generally in larger parcels of agricultural 1and. Several parcels are held by the State of California and by the Imperial Irrigation District, most of which is used as a waterfowl management area. Several small parcels, comprising about $5 \%$ of the area, are owned by geothermal development companies, Fig. 3. 


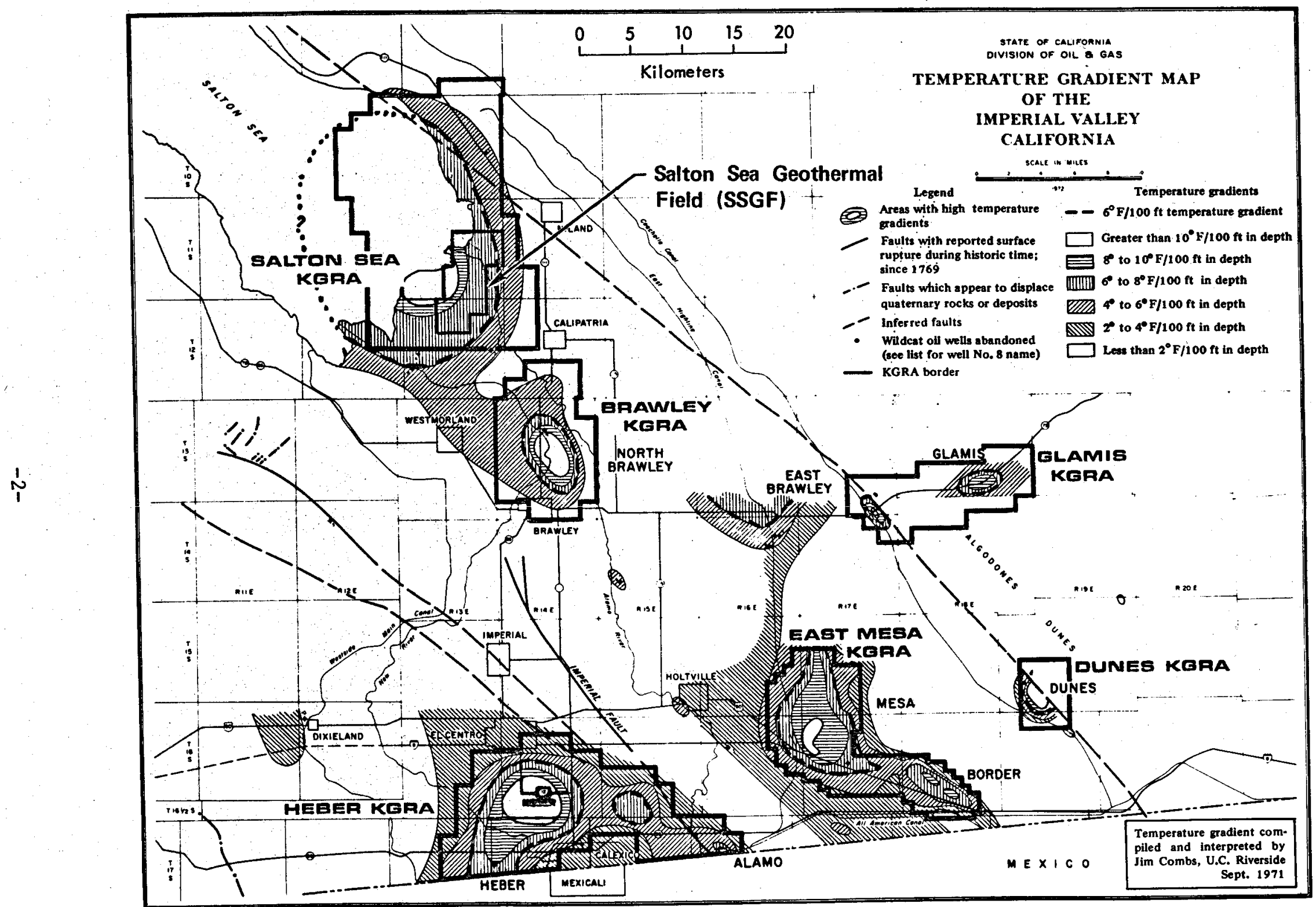

Fig. 1. Temperature gradient map of the Imperial Valley, California, showing Known Geothermal Resource Areas (KGRAs) and the Salton Sea Geothermal Field (SSGF). 


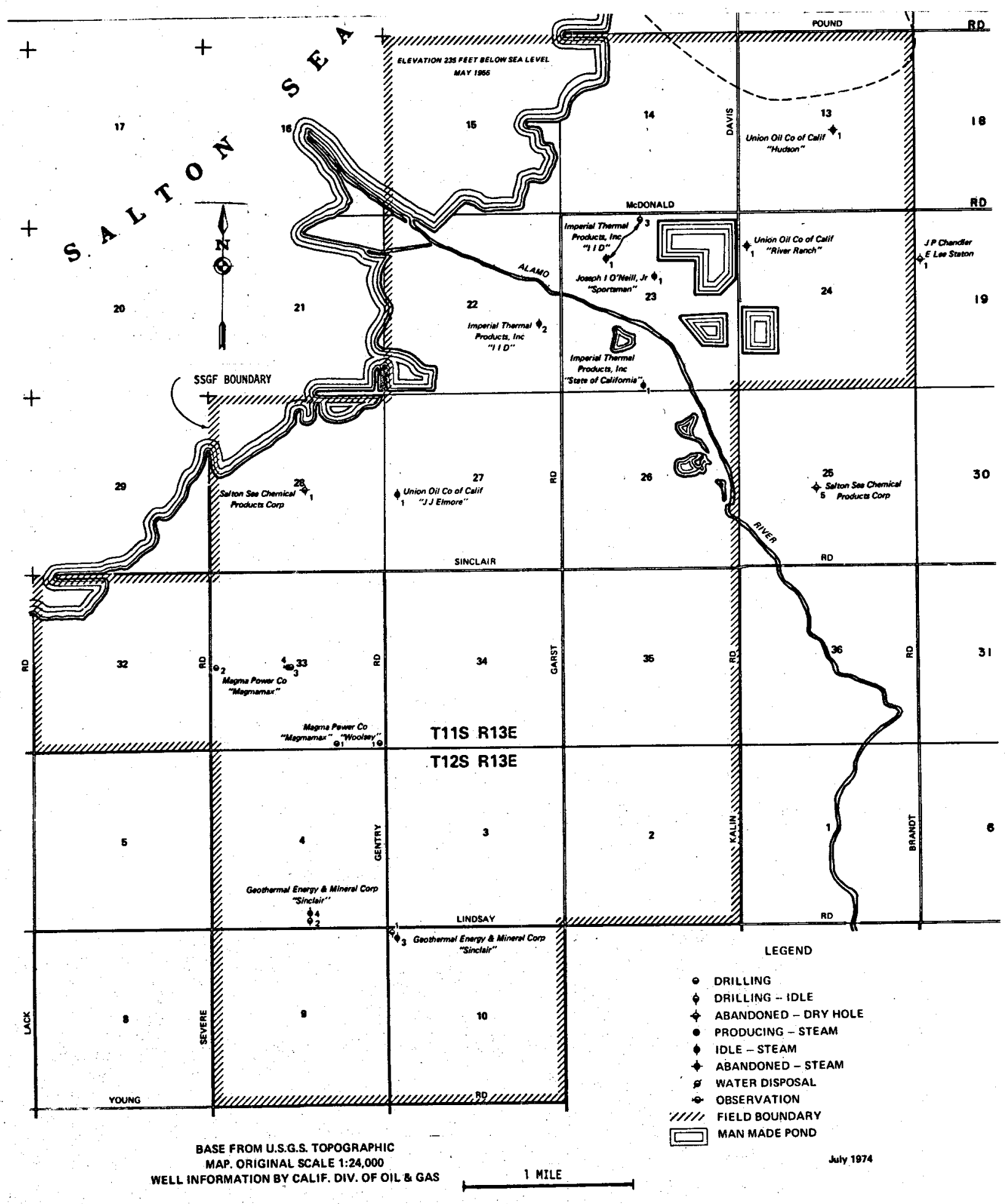

Fig. 2. Salton Sea Geothermal Field (SSGF) in Salton Sea KGRA. 


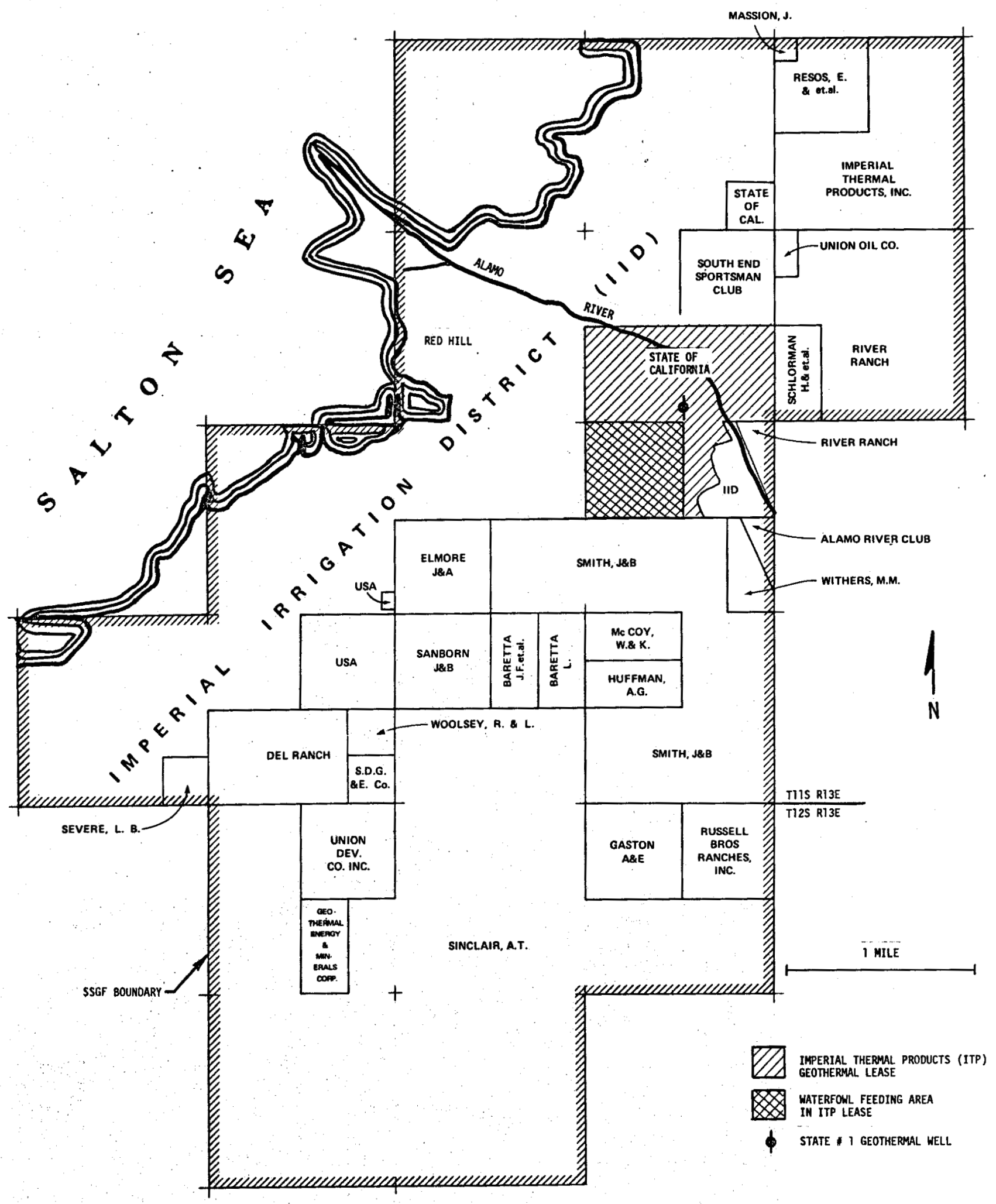

BASE FROM U.S.6.5. TOPOGRAPHIC MAP. ORIGINAL SCALE 1:24,000 JULY 1974

Fig. 3. Salton Sea Geothermal Field with surface ownership, ITP lease of State-of-California land, and waterfowl feeding area. 
Most of the land within the SSGF has been leased for geothermal development by various companies. The larger parcels of land included in these leases are illustrated in Fig. 4.

ERDA and Imperial Thermal Products, Inc. (ITP) propose to enter into a license agreement on ITP.'s geothermal lease from the State of California, covering portions of Sections 23 and 26, T.11S, R.13E. (535 acres), the shaded area in Fig. 3. This tract is a part of the Hazard Unit of the State's Imperial Waterfowl Management Area, operated by the U. S. Fish and Wildlife Service, the administrator of the local Salton Sea National Wildlife Refuge, under a Land Use Permit. The only present development in the Unit is a waterfow 1 feeding area sown to rye grass on a quarter section (cross hatched in Fig. 3) southwest of State $\#_{1}$ geothermal well site indicated in Figs. 2-4. Under the license agreement with ITP, ERDA proposes to produce brine from this existing geothermal well and to use the adjacent area to the west and north to conduct a program of field tests and experiments essential to solution of the technical problems that presently prevent economic development of the area's geothermal resources.

The SSGF is known to contain large amounts of hot water $\left(300-575^{\circ} \mathrm{F}\right)$, potentially capable of producing at least $400 \mathrm{MW}$ of electrical power for $20 \mathrm{yr}^{*}$ The technical difficulties preventing the commercial production of electrical power from this resource are related to brine handling, control of scaling, and the development of brine-tolerant power-conversion systems. The planned experiments at State 11 well are essential to the ERDA program for the study of these problems. The technical direction and management will be carried out by the University of California, Lawrence Livermore Laboratory (LLL) as part of its overal1 geothermal energy development program.

\section{Total Flow Concept}

The LLL geothermal project goal is to develop and transfer the technology required to generate electrical power from high temperature brines and to prove the feasibility of commercial power production. Earlier attempts at power generation disclosed severe problems of corrosion and scale buildup.

${ }^{*}$ D. Towse, An Estimate of the Geothermal Energy Resource in the Salton Trough, California, Lawrence Livermore Laboratory, Rept. UCRL-51851 (1975). 


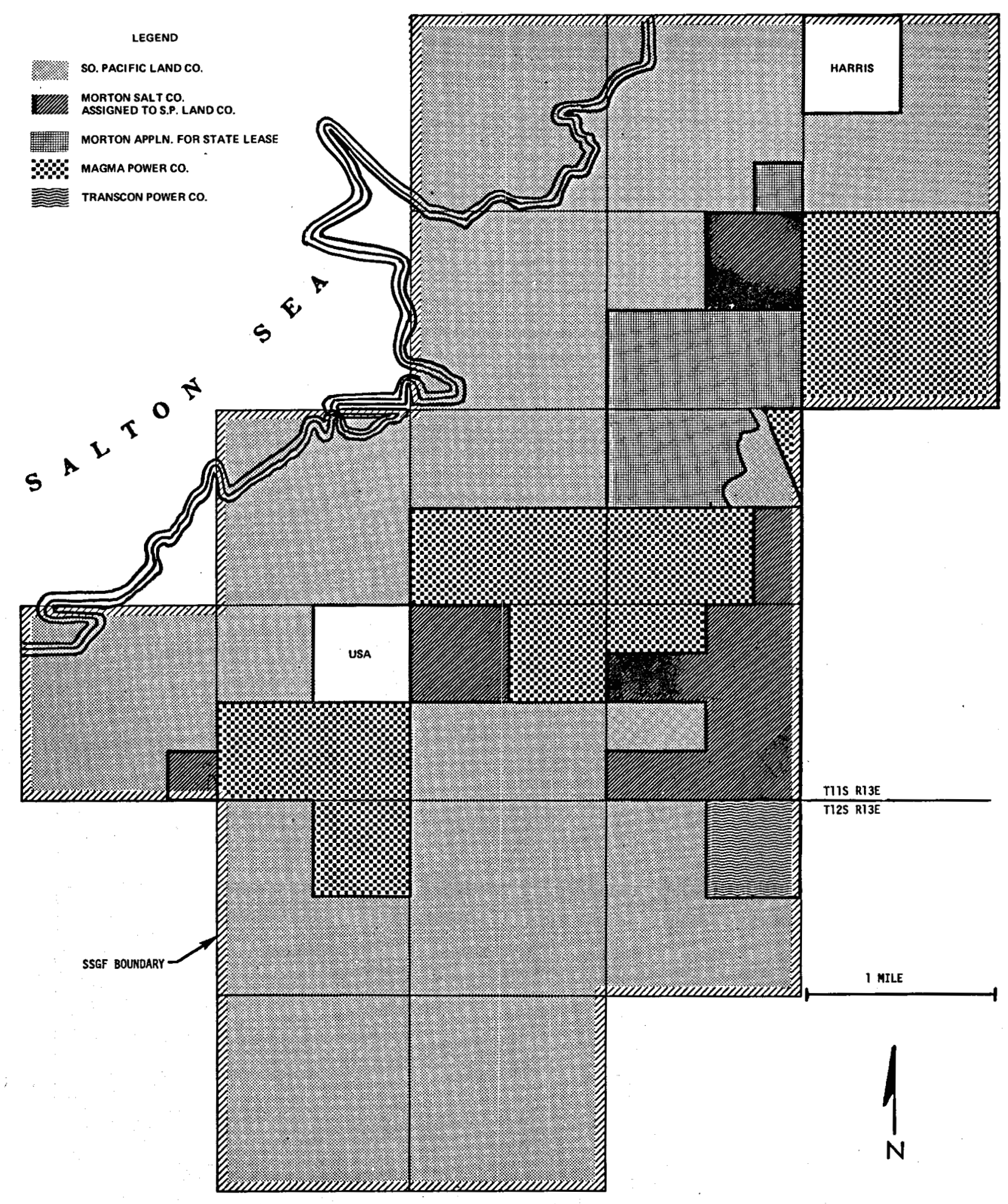

F1g. 4. Salton Sea Geothermal Field with geothermal leases. 
LLL proposes an entirely different approach, the Total Flow System. * In principle, this system consists of passing the total wellhead brine-steam mixture directly through a mixed-phase expander. Development of this concept could make it possible to produce energy from the Salton Sea field and similar geothermal fields throughout the world, and to do so with as much as $60 \%$ more power output than could be realized from alternative schemes.

\section{LLL Site Requirements}

To accomplish these ends, LLL requires access to an existing and producible geothermal well, capable of producing brine in sufficient quantity and with quality characteristic of a major part of the SSGF reservoir. Of the wells considered for this experiment, the State 11 has the best reservoir characteristics, is believed to be in good condition, and is available for full-time operation. All the other potential well sites are either unavailable for use, or have inadequate brine flow. Consequently, a license arrangement is proposed with Imperial Thermal Products, Inc., for use of the State $\# 1$ geothermal we11 site.

\section{PROJECT DESCRIPTION}

\section{Test Objectives}

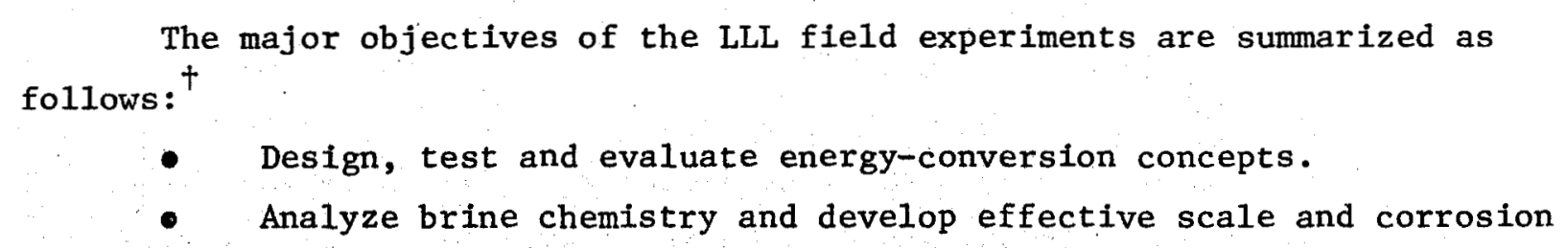
control methods.

- Identify brine-tolerant materials and fabrication methods.

- Build and operate a small-scale experimental power plant based on the Total Flow Concept.

\footnotetext{
*A. L. Austin, G. H. Higgins, and J. H. Howard, The Total Flow Concept for Recovery of Energy from Geothermal Hot Brine Deposits, Lawrence Livermore Laboratory, Rept. UCRL-51366 (1973).

tT. D. Palmer, J. H. Howard, and D. P. Lande, Eds., Geothermal Development of the Salton Trough, California and Mexico, Lawrence Livermore Laboratory, Rept. UCRL-51775 (1975).
} 


\section{Site Development}

In developing the site, LLL will need to inspect and refurbish the existing State $\#_{1}$ well for use as a source of hot, saline brine for the field experiment program. We also plan to build a temporary 20-acre brine holding and evaporation pond for disposal of brine produced during initial small scale flow experiments. The pond will be used as stand-by emergency storage during full-flow tests. Subsequent field test operations will necessitate the improvement of the surface area at the existing well site, which will accommodate instrumentation and diagnostic equipment, together with necessary brine lines, an access road, and utility connections. Most experimental equipment and support facilities will be housed in trailers parked on the site. The proposed site layout and development are shown as Figs. 5 and 6 .

\section{Site Operation}

Test site operations are outlined in Appendix A, beginning with well refurbishing and concluding with successful operation of an experimental power plant. Initial test and evaluation operations will measure brine characteristics in place and at the wellhead, develop methods for precipitation and scale control, testing of brine-tolerant materials, operation of up to 1-MW expander prototypes, and treatment of brine for reinjection.

These small-scale tests involve limited volumes of brine, requiring only enough ponded area to accommodate several days well production. The pond is sized with a safety factor to allow for retention of brine from up to two weeks of full-capacity well production. If these initial small-scale tests are successful, we plan to drill two more wells, one to produce larger volumes of brine and the other for disposing of them. These expanded facilities will support extended tests, primarily of prototype energy-conversion turbine systems. The reinjection well will also be used for studies of technical and environmental problems associated with the process of brine reinjection. Figure 5 shows proposed locations for these additional wells.

U1timately, the ERDA program includes development of an experimental power-plant system of about $10 \mathrm{MW}$ capacity in order to investigate the requirements of a commercial-size power-conversion system. This will involve a joint LLL/industrial program. 


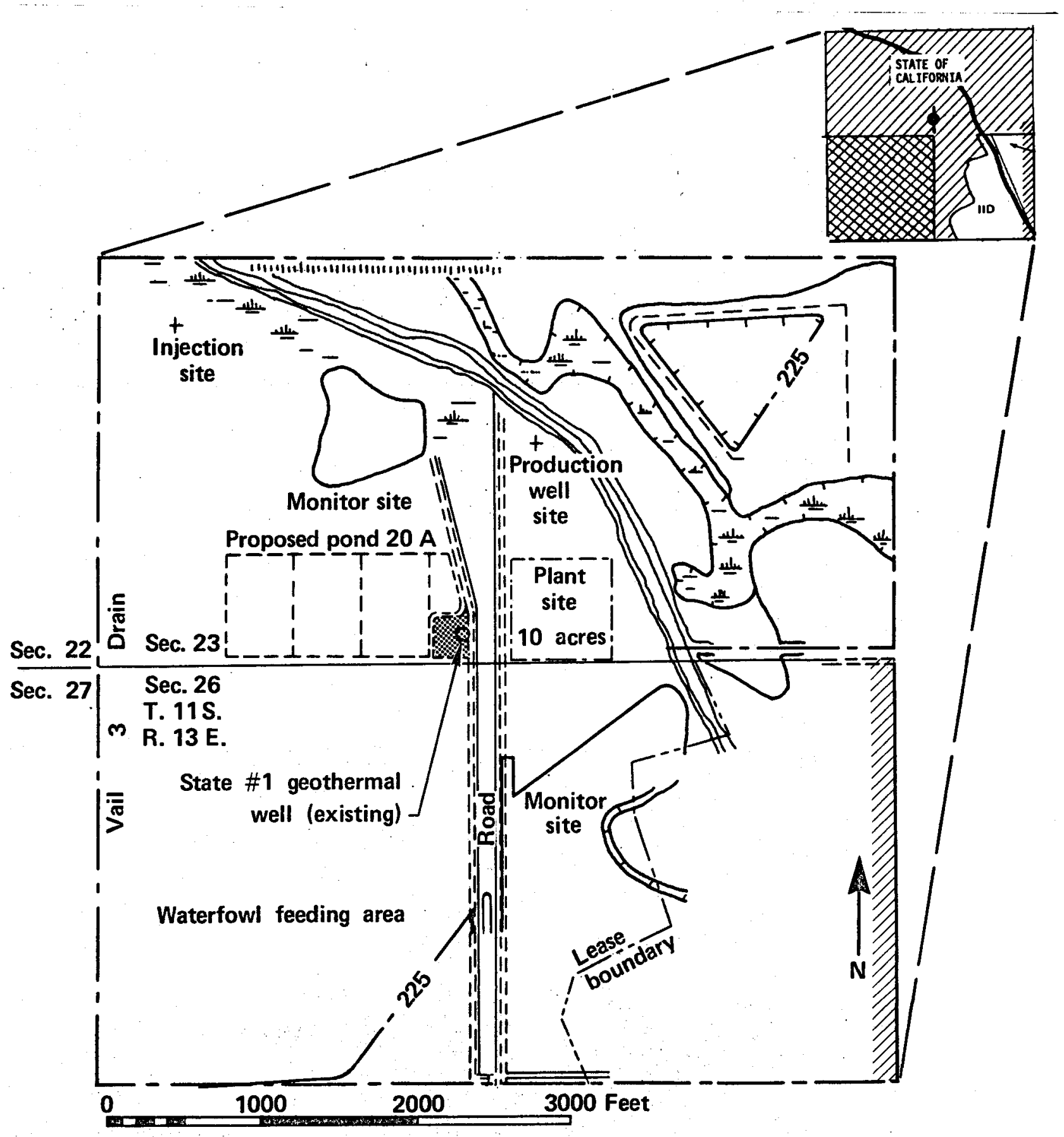

Fig. 5. Site layout for tests using State \#1 geothermal well. 


\section{C}

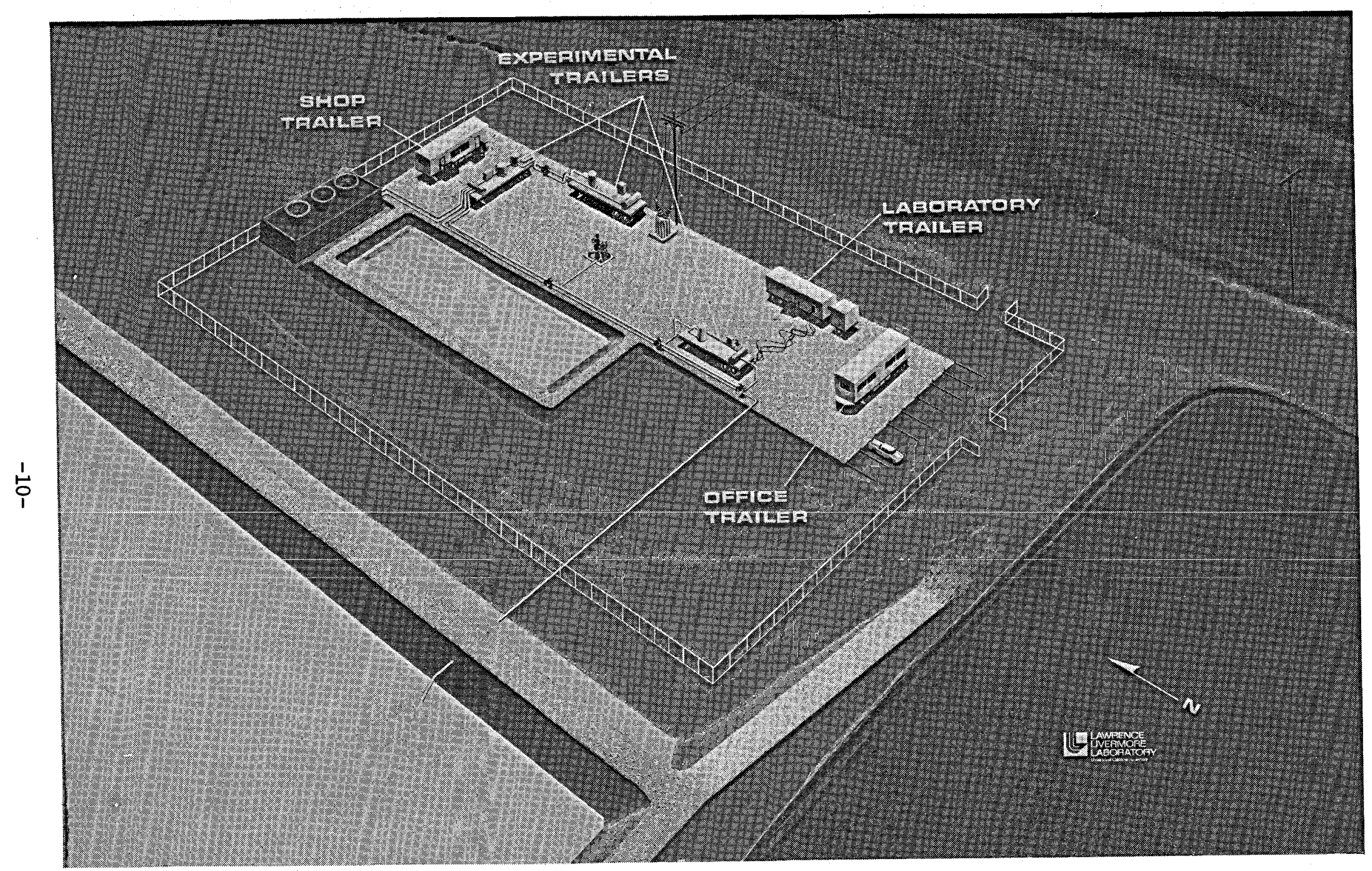

FIg. 6. Geothermal experimental site, State 非 well. $2,-\infty \gamma_{0}$ 


\section{Project Administration}

A11 project activities will be conducted by the University of California Lawrence Livermore Laboratory, under contract to ERDA. Site development and operation will be subject to and in accordance with requirements of the following agencies: California Division of $0 i 1$ and Gas, County of Imperial, California Regional Water Quality. Control Board, California Department of Fish and Game, and subject to the conditions of the existing geothermal lease between Imperial Thermal Products, Inc. and the State of California.

\section{ENVIRONMENTAL CONSIDERATIONS}

\section{Regulatory Agencies}

Environmental controls and surveillance will be maintained in accordance with requirements prescribed by agencies of the State, County, and regional authorities. Measures for control of potential environmental impacts are mandated by Imperial County's "Terms, Conditions, and Standards", by the State of California, Division of 011 and Gas regulations for completion of and production from geothermal wells, and by the California Regional Water Quality Control Board, which regulates discharge of geothermal brines. Because the proposed test activities will be on State of California land included in a Waterfow1 Management Area, the State Lands Commission has stipulated additional safeguards including special controls designed to preserve the use of the land for waterfow1 management. See Appendix B, Lease Conditions.

\section{ERDA Environmental Program}

The industrial development of the SSGF area is being preceded by an ERDA-sponsored research program to determine existing baseline physical and geological conditions and to predict environmental impacts. This project includes environmental surveillance of potential hazards throughout the developmental stages of the LLL and other research endeavors in the area. The project will evaluate and describe the baseline conditions of air, water, land, and general ecological quality throughout the immediate area. Changes in baseline conditions will be monitored during the geothermal development stage in order to predict and to alert government and industry to potential impacts. The first phase of the project will increase the number of air 
monitoring stations throughout the Imperial Valley and will extend the existing seismic surveillance network in the Salton Sea area. The LLL geothermal project will be a subscriber and a participant in the environmental project.

On Site Environmenta1 Program

In addition to the area-wide ERDA environmental program, particular attention will be given to the following aspects of on-site environmental problems.

- The wildlife refuge area will be restored to original condition or improved upon completion of the project.

- Drilling operations will be restricted to the summer months when no migrating waterfowl reside in the area.

- Noise associated with the site operation will be minimized in an attempt to avoid disturbing migrating waterfowl in adjacent fields.

- Disposal of the limited amounts of brine produced will be in accordance with requirements of the California Regional Water Quality Contro1 Board. Dumping or percolation of waste waters to adjacent land or water systems are not allowed. Solar evaporation will adequately remove water produced from the well, and residual salts will be periodically removed from the site and disposed of elsewhere.

- Flowlines and production systems will be designed to prevent salt spray damage to surrounding land and to keep emissions to the atmosphere within approved limits.

- Suitable provisions will be made to protect wildlife from any hazards in the brine holding ponds, should this be found necessary.

A seismic/subsidence survelllance system will be maintained for this site which will be tied into the existing local network and will be monitored on a regular basis. Significant movements effecting local land surface levels will be detected by this system.

Additionally, the LLL net of land surface level stations will be a part of the larger ERDA program to evaluate natural vertical ground movements in the entire area. Survelllance during production stages will provide early detection of any new induced movements.

It is not anticipated that ERDA experimental activities will result in significant earth surface movements due to the limited amounts of brine 
to be produced. When production volume is increased, reinjection will return fluids to the reservoir.

Successful completion of this project will provide a better understanding of the technology required to produce this and other potential heat resources throughout the world. A technology should result which will improve the efficiency of conversion to useful energy, and successful operation of an experimental power conversion facility could provide a new source of energy for the Southwest.

The land to be used in this project is not suitable for commercial agriculture due to excessive soll salinity. ' It is possible, however, to grow certain salt-tolerant grasses useful for the waterfowl management activities conducted within the area. Geothermally undeveloped land nearby is equally suited for that purpose. In the short-term, use of the land for an experimental site would make a sma11 portion of this land unavailable for grass production, and that use of the land for waterfowl management would be temporarily deferred for development of the experimental site. At termination of the project, the land could be returned to original or better condition and be available again for grass production. The intended long-term use of the land would, therefore, be unimpaired. 
LLL GEOTHERMAL DEVELOPMENT PROGRAM OVERVIEW

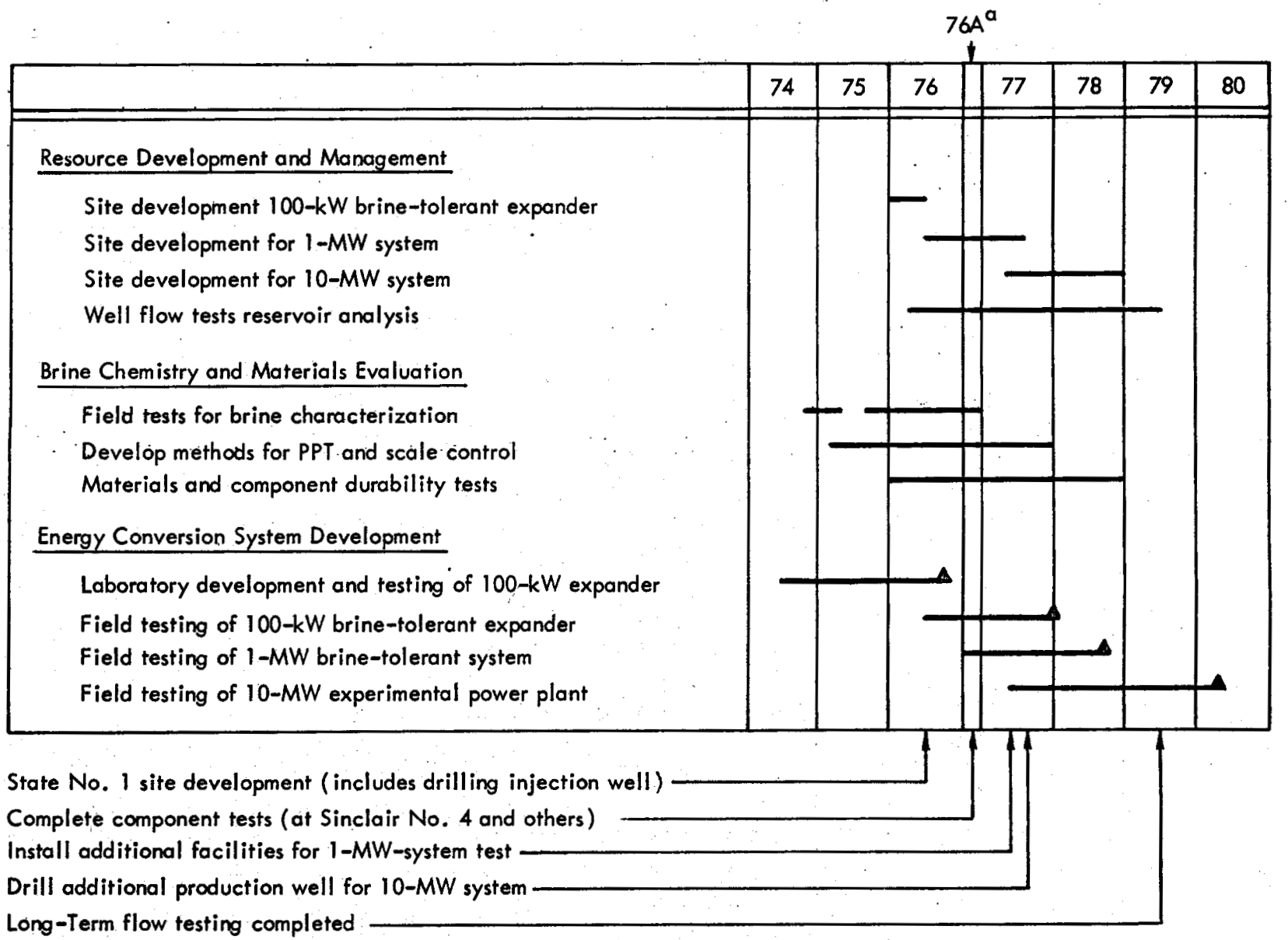

$a{ }_{F i s c a l}$ Year 76A covers the period from July 1, 1976 through September 30, 1976.

Fiscal Years 77, 78, 79, and 80 run from October 1 through the following September 30. 
APPENDIX B

\section{LEASE CONDITIONS}

(Conditions of California Department of Fish and Game, as attached to the Geothermal Resources Lease to Imperia1 Therma1 Products.)

1. All drilling shall be confined to a period from April 15 through September 15 in each year. Lessee shall conduct all of its activities at all times in such a manner as will not interfere with the purpose, function, and use of the Wister or Hazard Unit of the Imperial. Waterfowl Management Area by the Department of Fish and Game, Salton Sea National Wildlife Refuge, or the Salton Sea.

2. Lessee shall discharge no wastes detrimental to fish, plant life; or bird life where such waste may enter water on the Imperial Waterfowl Management Area, the Salton Sea National Wild1ife Refuge, or the Salton Sea.

3. Unless specifically permitted by the Department of Fish and Game, drill operations may not be conducted within 150 feet of areas ponded by the Department, or any area that the Department indicates in advance that it plans to pond in the foreseeable future. Nothing contained herein shall prevent the Lessee from creating ponds up to two (2) acres in size adjacent to each of its wells, provided that all flash steam from the wells be piped away and not exhausted into the atmosphere and that the average temperature of the water in the ponds does not exceed $150^{\circ} \mathrm{F}$.

4. Testing shall be conducted through calorimeters or a closed system. At no time shall steam be exhausted directly to the atmosphere.

5. Any existing roads used by the Lessee for operations under this lease shall be kept in good state of repair at all times at the sole expense of said Lessee.

6. The location of any roads to be constructed for access to well locations under this lease shall be approved in advance by the Department of Fish and Game. Such roads shall be constructed at the sole expense of Lessee of said lease. 
7. Surface equipment for all wells" drilled under this lease shall be located so as to be as inconspicuous as possible and with the approval of the Department.of Fish and Game first had and obtained.' All surface equipment necessary for well operations and handling of gas sha11 be painted and insulated in a manner to be approved b"y the Department of Fish and Game.

8. Unless specifically permitted by the Department of Fish and Game any pipe lines laid on the above described premises in connection with this lease shall be laid below plow depth and at least two.feet below the bottom of any irrigation or drainage ditch or slough. Appropriate markers shall be provided for all pipe lines to identify their locations.

9. Noise abatement equipment sha11 be used in a11 drilling and testing phases to preclude disturbance of wildlife habitat areas; and at no time shall noise be allowed to disturb wildlife areas.

10. The applicant shall contact $\mathrm{Mr}$. Robert Montgomery, Regional Manager, Department of Fish and Game, 350 Golden Shores, Long Beach, CA 90802; telephone (213) 435-7741, prior to any road construction, drilling activities, or well testing so the Department can monitor the impact of these activities on fish and game resources. The applicant will also implement appropriate corrective measures as recommended by the Department of Fish and Game if any substantial adverse impacts to fish and wildlife occur during project operations. 
NOTICE

"This report was prepared as an account of work sponsored by the United States Government, Neither the United States nor the United States Energy the United States nor the Udministration nor any Research \& Dev of their employees, nor any of their contractors, subcontractors, or their employees, makes any warranty express or implied, or assumes any legal Warranty, express or implity for the accuracy completeness or usefulness of any information apparatus, product or process disclosed, or tepresents that its use would not infringe privately-owned rights."

Printed in the United States of America Available from

National Technical Information Service

U.S. Department of Commerce 5285 Port Royal Road

Springfield, Virginia 22151

Price: Printed Copy $\$ *$; Microfiche $\$ 2.25$

$*$ Pages
$1-50$
$51-150$
$151-325$
$326-500$
$501-1000$

NTIS

Selling Price

$\$ 4.00$

$\$ 5.45$

$\$ 7.60$

$\$ 10.60$

$\$ 13.60$ 